\title{
高速向流クロマトグラフィーによる鵎卵卵黄中の リン脂質の分離
}

\author{
渋沢 庸一 ${ }^{\circledR 1}$, 竹内 尚子 ${ }^{1}$, 神藤平三郎 ${ }^{1}$, 伊東洋一郎 ${ }^{2}$
Separation of Phospholipids from Hen Egg Yolk by High-Speed Countercurrent Chromatography

\begin{abstract}
Yoichi Shibusawa $^{1}$, Naoko TAkeuchi ${ }^{1}$, Heisaburo Shindo $^{1}$ and Yoichiro Ito $^{2}$
${ }^{1}$ Division of Structural Biology and Analytical Science, Tokyo University of Pharmacy and Life Science, 1432-1, Horinouchi, Hachioji-shi, Tokyo 192 - 0392

${ }^{2}$ Laboratory of Biophysical Chemistry, National Heart Lung, and Blood Institue, National Institutes of Health, Bethesda, Maryland, USA
\end{abstract}

(Received 27 June 2005, Accepted 31 August 2005)

\begin{abstract}
Phospholipids were fractionated by high-speed counter-current chromatography in a one-step operation from about $0.75 \mathrm{~g}$ of hen egg yolk using a type J-multilayer coil planet centrifuge. The partition coefficients values of phospholipids were measured in several two or three-solvent systems. The separation of phospholipids was performed with a two-phase solvent system composed of chloroform/ $n$-heptane/ $n$-butanol/methanol/60\% acetic acid (2:3:2:3:5) by eluting the lower phase at a flow-rate of $1.0 \mathrm{ml} / \mathrm{min}$. The phospholipids in each fraction were characterized by thin-layer chromatography.
\end{abstract}

Keywords : countercurrent chromatography; two or three-phase systems; hen egg yolk phospholipids ; partition coefficient.

\section{1 緒 言}

Ito らにより開発された向流クロマトグラフィー（CCC） は二相系の片方の相の液体を重力又は遠心力でカラム内に 保持し，固定相とする真の液-液分配クロマトグラフィー である ${ }^{1) ~ 4)}$ 。この方法は, 液-液分配法である向流分配法 (countercurrent distribution, CCD) と, 連続的な溶出方 法である液体クロマトグラフィー（LC）の両法の長所を 併せ持っている. 1980 年代の前半, 回転するコイル状カ ラム内ではアルキメデスのスクリュー効果が生じ，固定相 と移動相との間に動的平衡が成立することが報告され ${ }^{5)}$, この動的平衡状態で物質を分離する高速向流クロマトグラ

\footnotetext{
${ }^{1}$ 東京薬科大学薬学部構造生物分析学教室：192-0392 東京都八 王子市堀之内 1432-1

${ }^{2}$ Laboratory of Biophysical Chemistry, National Heart Lung, and Blood Institue, National Institutes of Health: 50 South Drive, Building 50, Room 3334, Bethesda, MD 20892, USA
}

フィー ( high-speed countercurrent chromatography, HSCCC）が開発された.HSCCC は従来の静的平衡状態 で物質を分離する液滴向流クロマトグラフィー（droplet countercurrent chromatography, DCCC) ${ }^{3)}$ や回転式多段 向流クロマトグラフィー（rotation locular countercurrent chromatography, RLCCC) ${ }^{2) 7)}$ ，三鬼式遠心クロマトグラ フィー（Sanki centrifugal partition chromatography, $\mathrm{CPC})^{8)}$ に比較して分離効率が格段に高く，各種物質の分 離に適用されるようになった. HSCCC はカラム充填剂を 使用する一般のクロマトグラフィー系に比べ, 大量の固定 相液体を使用することができるため，大量の物質の分取に 適している。また，カラム充填剤を使用しないので分析試 料の非可逆的吸着が全く起こらない. 更に, 固定相に親和 性が高く移動相では溶出できない物質でも, 固定相が液体 であるので固定相液体でカラム内から回収できる大変特徴 のあるクロマトグラフィーである. 


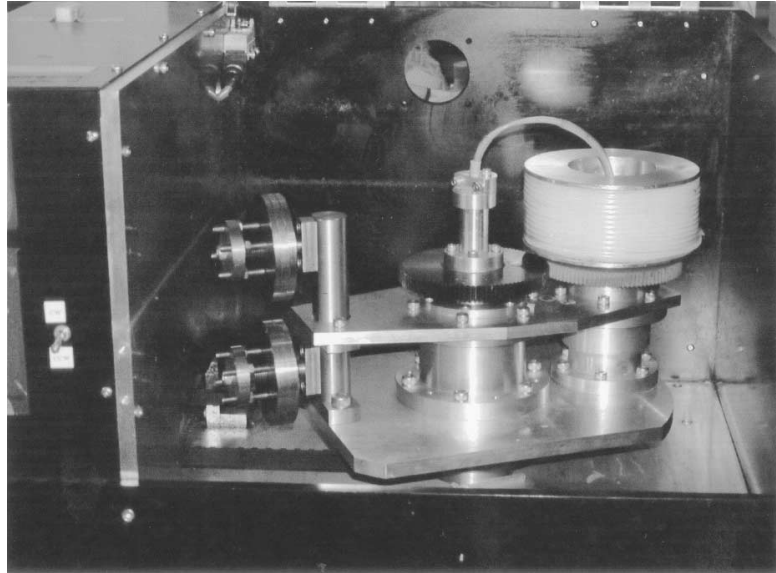

Fig. 1 Photograph of type-J coil planet centrifuge

HSCCC を行うため各種の遠心装置が工夫され開発され てきた。それれの中でも HSCCC に用いられるJ 型コイル プラネット遠心装置（type J coil planet centrifuge, J$\mathrm{CPC})^{9)}$ は固定相液体のカラム内への保持に優れ, カラム 効率が良いので，この装置と水・有機溶媒の二相系とを用 いて多くの物質が分離されている. また, 近年, ヘキサン, 酢酸メチル，アセトニトリル，水から成る三相系の下層を $\mathrm{J}-\mathrm{CPC}$ のカラムへ固定相として保持させ，中間層を移動相 に用いてカテキン重合体を重合度別に分離した例も報告さ れている ${ }^{10)}$.

鶏卵卵黄中には約 $65 \%$ のトリグリセリド， $30 \%$ のリン 脂質， $5 \%$ のコレステロールが含有されている ${ }^{11)}$.このリ ン脂質の $86.2 \%$ がホスファチジルコリン（PC），11.9\% がホスファチジルエタノールアミン（PE），1.9\% がスフ インゴミエリン（SM）であり, 特に, PE は血清総コレス テロール量を低下させ高密度リポタンパク質 (HDL) コレ ステロール值を上昇させる作用があるとされている ${ }^{12) 13) .}$ また，PC，SM は神経伝達物質のアセチルコリンの前駆体 であるコリンを含有することから, 脳内コリン濃度を高め, 学習改善効果が期待されている ${ }^{14)}$. また, リン脂質から構 成されるリポソームは生体機能解析のモデル系, 膜作用物 質の機能, 細胞機能の解析などの基礎研究に利用されてい る。また，制がん剂，抗生物質などの薬物をリポソームに 組み达んで患者に投与し, 患部に薬剤を運ぶ治療に利用さ れている。このように，リン脂質は多方面で利用されて おり，大量に分離精製されることが望まれている.

静的平衡状態で分離を行う DCCC で糖脂質を分離した 例 $\left.{ }^{15)} \sim 17\right)$ や, Sanki CPC で脂質, リン脂質などを分離した 例 ${ }^{1819)}$ や動的平衡状態に扔ける J-CPC でヒト脳細胞中のリ ン脂質又は糖脂質を分析的レベルで分離した例 ${ }^{20221}$ は報告 されているが，鷄卵卵黄中のリン脂質を分取した例はいま だ報告されていない.

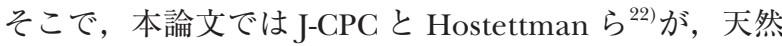
物の分離に利用した多成分系から成る水・有機溶媒の二相 系又は三相系とを用いて, 鶏卵卵黄中のリン脂質, 特に PC と PEの分取について検討した.

$$
2 \text { 実験 }
$$

\section{$2 \cdot 1$ 装 置}

Fig. 1 にJ 型コイルプラネット遠心装置（J-CPC）（日立 東京エレクトロニクス製）の写真を示した。装置は遠心軸 から $10 \mathrm{~cm}$ の位置にカラムホルダーがあり, カウンター ウエイトでバランスをとっている. 分離カラムはカラムホ ルダー上に内径 $2.6 \mathrm{~mm}$ 長さ $31.0 \mathrm{~m}$ のテフロンチューブ を 8 層に巻いて調製した (カラム容量 : $165 \mathrm{ml}$ ).カラム が横方向の公転周期に同調しながらカラム自身横方向に自 転する，その結果，回転によるチューブのねじれを解消し ながら, カラム内で固定相液体と移動相液体の十分な混和 が達成される。最初は固定相がカラムから漏れ出すが, 固 定相と移動相とがカラム内で動的平衡状態に達して定常状 態になると，移動相だけが溶出する。

\section{$2 \cdot 2$ 試 薬}

$n$-ペンタン, $n$-ヘキサン, $n$-ヘプタン, アセトニトリル 酢酸メチル，クロロホルム，n-ブタノール，メタノール， 酢酸（関東化学製）は市販の特級品を使用した。ホスファ チジルコリン，ホスファチジルエタノールアミン (SIGMA 製) は分配係数の測定に使用した。その他の試薬 はすべて試薬特級品を使用した。

\section{$2 \cdot 3$ 有機溶媒・水系の二相，三相溶媒系}

次の溶媒系を調製した。(1) 酢酸メチル, $n$-ヘキサン, アセトニトリル，水系の二相又は三相系 6 種類, (2) クロ ロホルム, $n$-ペンタン, $n$-ブタノール, メタノール, 水の 二相系 4 種類, (3) クロロホルム, $n$-ペンタン, $n$-ブタ) 一ル，メタノール， $60 \%$ 酶酸の二相系 4 種類, (4) クロロ ホルム， $n$-ヘキサン， $n$-ブタノール，メタノール，水の二 相系 4 種類, (5) クロロホルム, $n$-ヘキサン,$n$-ブタノー ル，メタノール， 60\% 酢酸の二相系 6 種類，(6) クロロホ ルム, $n$-ヘプタン,$n$-ブタノール, メタノール，水の二相 系 4 種類，(7) クロロホルム，n-ヘプタン, $n$-ブタノール, メタノール，60\% 酢酸の二相系 6 種類合計 34 種類につい て, 二相系においては上層（UP） と下層（LP）の体積比 (UP/LP), 三相系については, 上層 (UP), 中間層 (MP), 下層（LP）の体積比（UP/MP/LP）を測定し，CCCによ るリン脂質の分離・分取に適用できるか否かを評価した。

\section{$2 \cdot 4$ 標準リン脂質の分配係数の測定}

調製した二相系又は三相系は分液漏斗中で十分にかくは 
Table 1 Phase composition of methyl acetate/n-hexane/acetonitrile/water systems

\begin{tabular}{ccccccc}
\hline Solvent systems & Methyl acetate & $n$-Hexane & Acetonitrile & Water & Phases & UP/MP/LP ratio ${ }^{\text {a) }}$ \\
\hline 1 & 5 & 5 & 1 & 5 & 2 & $1.3 / 1$ \\
2 & 5 & 5 & 2 & 5 & 2 & $1.4 / 1$ \\
3 & 5 & 5 & 4 & 5 & 3 & $2 / 2 / 3$ \\
4 & 5 & 5 & 5 & 5 & 3 & $1.8 / 2.4 / 3$ \\
5 & 5 & 5 & 5 & 10 & 3 & $2 / 3 / 3$ \\
6 & 5 & 5 & $4.2 / 1.4 / 6$ \\
\hline
\end{tabular}

a) Volume ratios for UP/LP for two phase systems, UP/MP/LP for three phase systems, UP: upper phase, MP: middle phase, LP: lower phase



Phosphatidyl choline (PC)

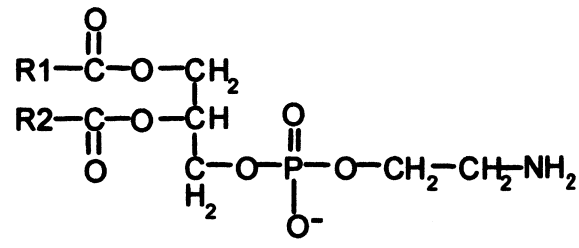

\section{Phosphatidyl ethanolamine (PE)}

Fig. 2 Chemical structures of phosphatidyl choline (PC) and phosphatidyl ethanolamine (PE)

んし平衡化した後に使用した。二相系の上層と下層及び三 相系の上層と中間層をそれぞれ $1.5 \mathrm{ml}$ を試験管に取り, 各々 $1 \mathrm{mg}$ の PC, PEを加えて 1 分間激しくかくはん後, 二相に分離した後，上層，下層又は上層と中間層をそれぞ れ $0.5 \mathrm{ml}$ 試験管に取り, メ夕ノール $1 \mathrm{ml}$ を加えて 250 $\mathrm{nm}$ における吸光度を Shimadzu UV-1200 分光光度計（島 津製）で測定した。二相系においては上層の吸光度を下層 の吸光度で除して分配係数 $\left(K=C_{\mathrm{U}} / C_{\mathrm{L}} ; C_{\mathrm{U}}, C_{\mathrm{L}}\right.$ はそれ ぞれ上層と下層中の $\mathrm{PC}, \mathrm{PE}$ 濃度) を算出し, 三相系につ いては上層の吸光度を中間層の吸光度で除して分配係数 $\left(K=C_{\mathrm{U}} / C_{\mathrm{M}} ; C_{\mathrm{U}}, C_{\mathrm{M}}\right.$ は上層と中間層の $\mathrm{PC}, \mathrm{PE}$ 濃度 $)$ を 算出した。

\section{$2 \cdot 5$ 向流クロマトグラフィー用試料の調製}

向流クロマトグラフィー用試料は鷄卵卵黄から BlighDyer 法 ${ }^{23)}$ に従って調製した。鶏卵 2 個から約 $32 \mathrm{ml}$ の卵 黄を得る。これをかくはんしながらメタノール $72 \mathrm{ml}$, 続 いてクロロホルム $36 \mathrm{ml}$ を加え 30 分間放置する。これに, 水 $43.2 \mathrm{ml}$, クロロホルム $36 \mathrm{ml}$ を加えよくかくはんして から, 遠心分離する。下層のリン脂質含有クロロホルム層
を減圧乾固し，向流クロマトグラフィー用試料とする.

$2 \cdot 6$ 向流クロマトグラフィー

$2 \cdot 3$ で調製した溶媒系を用いて PC，PE の分配係数を求 めるとともに，これらのリン脂質がミセルを形成しない, クロロホルム $: n$-ヘプタン : $n$-ブタノール : メタノール : $60 \%$ 酢酸 $=2: 3: 2: 3: 5$ の系を鶏卵卵黄試料の CCC 分 離に用いた。

まずJ-CPCのカラムに固定相である上層をポンプで満 たした後， $2 \cdot 5$ で調製した試料 $0.75 \mathrm{~g}$ に二相系の上層と下 層とをそれぞれ $2 \mathrm{ml}$ 加えて溶かした試料溶液をサンプル ループから注入した．カラムを $1000 \mathrm{rpm}$ で回転させ，移 動相である下層を流量 $1.0 \mathrm{ml} / \mathrm{min}$ で送液した。溶出液の $250 \mathrm{~nm}$ における吸光度を, UV-9000 型検出器（東京理化 器械製）で測定し，クロマトグラムを作成するとともに， REDIRAC 2112 型フラクションコレクター（LKB 製）で 分取した. 分画した画分中の PC, PE はシリカゲル薄層ク ロマトグラフィー（展開溶媒：クロロホルム，メタノール， 水 $=65: 25: 4)$ で展開乾燥後, $55 \%$ 硫酸- $0.6 \%$ 重ク口 厶酸混液を噴霧し発色させ確認した ${ }^{24)}$.

\section{3 結果と考察}

\section{$3 \cdot 1$ 二相，三相溶媒系}

有機溶媒 3 種類と水とから構成される酢酸メチル: $n$-へ キサン：アセトニトリル：水の混合比を各種変化させた， 二相又は三相系 6 種類を Table 1 に示した。酢酸メチル： $n$-ヘキサン: 水 $=5: 5: 5$ にアセトニトリルを 1 又は 2 混 合した溶媒系は二相を形成し，アセトニトリルの混合比が 3 以上に増大すると三相系を形成する。それぞれの溶媒系 の上中下層の比（UP : MP : LP）も同時に示した.これら の溶媒系において, Fig. 2 に示す, PC と PE の溶解性, ミセルの形成状態などを観察した。溶媒系（上下層各 1.5 $\mathrm{ml}$ 又は上中層各 $1.5 \mathrm{ml}$ ）に $\mathrm{PC}, \mathrm{PE}$ をそぞれ約 $1 \mathrm{mg}$ 加 え，よく混和後，静置し相分離させた。その結果，PCは いずれの溶媒系にもよく溶解し，ミセルの形成は観察され なかった。しかしながら，PEはすべての溶媒系において ミセルを形成し，界面に分布することが分かった。このこ 
Table 2 Phase volume ratios of several two phase systems including chloroform

\begin{tabular}{|c|c|c|c|c|c|c|c|c|c|}
\hline \multirow{2}{*}{ Solvent systems } & \multicolumn{9}{|c|}{ Volume tatios } \\
\hline & Chloroform & $n$-Pentane & $n$-Hexane & $n$-Heptane & $n$-Butanol & Methanol & Water & $60 \%$ acetic acid & $\mathrm{UP} / \mathrm{LP}^{\mathrm{a})}$ \\
\hline 1 & 1 & 1 & - & - & 1 & 1 & 2 & - & 0.88 \\
\hline 2 & 1 & 2 & - & - & 1 & 1 & 5 & - & 0.31 \\
\hline 3 & 1 & 3 & - & - & 1 & 1 & 5 & - & 0.72 \\
\hline 4 & 1 & 3 & - & - & 3 & 1 & 5 & - & 1.10 \\
\hline 5 & 1 & 1 & - & - & 1 & 1 & - & 2 & 0.07 \\
\hline 6 & 1 & 2 & - & - & 1 & 1 & - & 5 & 0.23 \\
\hline 7 & 1 & 3 & - & - & 3 & 1 & - & 5 & 0.21 \\
\hline 8 & 2 & 3 & - & - & 2 & 3 & - & 5 & 0.11 \\
\hline 9 & 1 & - & 1 & - & 1 & 1 & 2 & - & 1.00 \\
\hline 10 & 1 & - & 2 & - & 1 & 1 & 5 & - & 0.67 \\
\hline 11 & 1 & - & 3 & - & 1 & 1 & 5 & - & 0.81 \\
\hline 12 & 1 & - & 3 & - & 3 & 1 & 5 & - & 1.20 \\
\hline 13 & 1 & - & 1 & - & 1 & 1 & - & 2 & 0.30 \\
\hline 14 & 1 & - & 2 & - & 1 & 1 & - & 5 & 0.41 \\
\hline 15 & 1 & - & 3 & - & - & - & - & 5 & 1.00 \\
\hline 16 & 1 & - & 3 & - & 1 & 1 & - & 5 & 0.60 \\
\hline 17 & 1 & - & 3 & - & 3 & 1 & - & 5 & 0.44 \\
\hline 18 & 2 & - & 3 & - & 2 & 3 & - & 5 & 0.24 \\
\hline 19 & 1 & - & - & 1 & 1 & 1 & 2 & - & 0.93 \\
\hline 20 & 1 & - & - & 2 & 1 & 1 & 5 & - & 0.59 \\
\hline 21 & 1 & - & - & 3 & 1 & 1 & 5 & - & 0.77 \\
\hline 22 & 1 & - & - & 3 & 3 & 1 & 5 & - & 0.72 \\
\hline 23 & 1 & - & - & 1 & 1 & 1 & - & 2 & 0.17 \\
\hline 24 & 1 & - & - & 2 & 1 & 1 & - & 5 & 0.34 \\
\hline 25 & 1 & - & - & 3 & - & - & - & 5 & 0.74 \\
\hline 26 & 1 & - & - & 3 & 1 & 1 & - & 5 & 0.49 \\
\hline 27 & 1 & - & - & 3 & 3 & 1 & - & 5 & 0.45 \\
\hline 28 & 2 & - & - & 3 & 2 & 3 & - & 5 & 0.23 \\
\hline
\end{tabular}

a) UP: upper phase, LP: lower phase

Table 3 Partition coefficient of PC and PE

\begin{tabular}{|c|c|c|c|c|c|c|c|c|}
\hline \multirow{2}{*}{ Solvent system } & \multicolumn{6}{|c|}{ Solvent composition (ratio) } & \multicolumn{2}{|c|}{ Partition coefficient } \\
\hline & Chloroform & $n$-Hexane & $n$-Heptane & $n$-Butanol & Methanol & $60 \%$ acetic acid & $K_{\mathrm{PC}}$ & $K_{\mathrm{PE}}$ \\
\hline 15 & 1 & 3 & - & - & - & 5 & 33.20 & 10.40 \\
\hline 16 & 1 & 3 & - & 1 & 1 & 5 & 2.67 & 10.10 \\
\hline 25 & 1 & - & 3 & - & - & 5 & 2.27 & 2.30 \\
\hline 28 & 2 & - & 3 & 2 & 3 & 5 & 0.87 & 1.98 \\
\hline
\end{tabular}

とは，PEはPCよりもメチル基が 3 つ少なく（Fig. 2)， 両親媒性の度合いが PCよりも強いためミセルを形成しや すいと考えられた。

次に, クロロホルムを含む有機溶媒 4 種類と, 水又は $60 \%$ 酢酸とから成る 3,5 成分系の二相溶媒系 28 種類に ついて (Table 2)，PC，PEの分配挙動を観察した。 $n$-ペ ンタン（溶媒系 $1 \sim 8 ）, n$-ヘキサン（溶媒系 9 〜 18), $n$ ヘプタン（溶媒系 19〜28）含有の 3 つのグループの溶媒 系の中で, 水を含有する系（溶媒系 1 ～4, 9 12, 19 22）の中では，PC，PEはいずれもミセルを形成した。ま た， $60 \%$ 酢酸の含有比が少ない溶媒系 5，13，23 は上層 の体積が下層の体積に比べて, 極端に少ないことが分かっ た. そこで, 溶媒系 $1 \sim 4,9 \sim 12,19 \sim 22$ と溶媒系 5, 13，23 を除いた溶媒系の中から $n$-ヘキサン含有の系から
は上層と下層の体積比が 1 に近い 15 と 16 の溶媒系を選 び，この系よりもリン脂質をよく溶解する $n$-ヘプタンを 含有する系からは，上層と下層の体積比が最大である 25 と最小である 28 の系を選択し，PC，PEの分配係数を測 定した。

\section{$3 \cdot 2$ リン脂質の分配係数 $(K)$ の測定}

$3 \cdot 1$ で選んだ二相溶媒系 $15 ， 16 ， 25 ， 28$ に PC と PEを それぞれ分配させ，分配係数（K） を求めた（Table 3). 一般に，CCCで物質を分離する場合， $K$ は 0.1 から 10.0 の範囲の物質の分離に有効であり, 1.0 前後が最も良い分 離が可能であるといわれている ${ }^{25)}$.なぜならば，下層を固 定相，上層を移動相に用いると $K$ が 10 以上の物質は，下 層の固定相にほとんど保持されず溶媒先端（solvent front, 
SF）に溶出する。また， $K$ が 0.1 以下の物質は下層の固定 相への親和性が高いため溶出するのに長時間を要する。一 方，上層を固定相，下層を移動相に用いると $K$ が大きな 物質は溶出するのに長時間を要するし， $K$ が小さな物質 はカラムを素通りし， SF に溶出する.

CCC は真の分配クロマトグラフィーであるので, CCC



Fig. 3 Purification of phospholipids from hen egg yolk by countercurrent chromatography

Experimental conditions: apparatus: type-J coil planet centrifuge with a multilayer coil column of $165 \mathrm{ml}$ total capacity; solvent system : chloroform/ $n$-heptane/ $n$-butanol/methanol/60\% acetic acid (2:3:2:3:5); stationary phase: upper phase; mobile phase: lower phase; sample: $0.75 \mathrm{~g}$ of hen egg yolk $+2.0 \mathrm{ml}$ upper phase $+2.0 \mathrm{ml}$ lower phase; flow-rate: $1.0 \mathrm{ml} / \mathrm{min}$; revolution : $1000 \mathrm{rpm}$; $\mathrm{SF}$ : solvent front; UP : upper phase was eluted from this fraction
による分離の成否は分離する物質の分配係数の差に大きく 依存する. Table 3 には二相溶媒系の組成と, PC と PE の 分配係数 $\left(K_{\mathrm{PC}}, K_{\mathrm{PE}}\right)$ を示した. クロロホルム : $n$-ヘキサ ン: $60 \%$ 酢酸 $=1: 3: 5$ の溶媒系 15 においては, $K_{\mathrm{PC}}$, $K_{\mathrm{PE}}$ はいずれも 10 以上であり， $\mathrm{PC}, \mathrm{PE}$ とも上層への親和 性が高すぎるため CCC には適さない。また，クロロホル ム : $n$-ヘキサン : $n$-ブタノール : メタノール $: 60 \%$ 酢酸 $=$ $1: 3: 1: 1: 5$ の溶媒系 16 では， $K_{\mathrm{PC}}, K_{\mathrm{PE}}$ に大きな差が認 められる。しかしながら, 鶏卵卵黄中には疎水性の脂質が 含有され， CCC で PCと PE は分離できたとしても， $K_{\mathrm{PE}}$ の大きな PE は他の単純脂質などの脂質とは分離できない と考えられる.

次に，25の溶媒系では $K_{\mathrm{PC}}, K_{\mathrm{PE}}$ はほぼ等しくなり $\mathrm{CCC}$ では PC と PE とは分離できないことが推察された。 クロロホルム $: n$-ヘプタン : n-ブタノール : メタノール : $60 \%$ 酢酸 $=2: 3: 2: 3: 5$ の二相系 28 において $K_{\mathrm{PC}}$ と $K_{\mathrm{PE}}$ は $0.87,1.98$ であり，適度な差が認められるので，これ らのリン脂質の CCC 分離に適用できると考えられた。こ の系は，上層と下層の比が 0.23 でこのように，上層又は 下層の体積が極端に異なる二相系は，体積の少ない相を移 動相に用いる場合には大量の二相溶媒系を調製しなければ ならないので CCC の溶媒系には不利であるが，分配係数 に適度な差が認められることや PC，PEをよく溶解するな どの点を考慮するとこの二相系 28 をリン脂質の分離に使 用することにした。

\section{$3 \cdot 3 \mathrm{CCC}$ による鶏卵卵黄中の PC，PE の分離}

クロロホルム $: n$-ヘプタン : $n$-ブタノール : メタノール : $60 \%$ 酢酸 $=2: 3: 2: 3: 5$ の二相系と J-CPC とを用いた

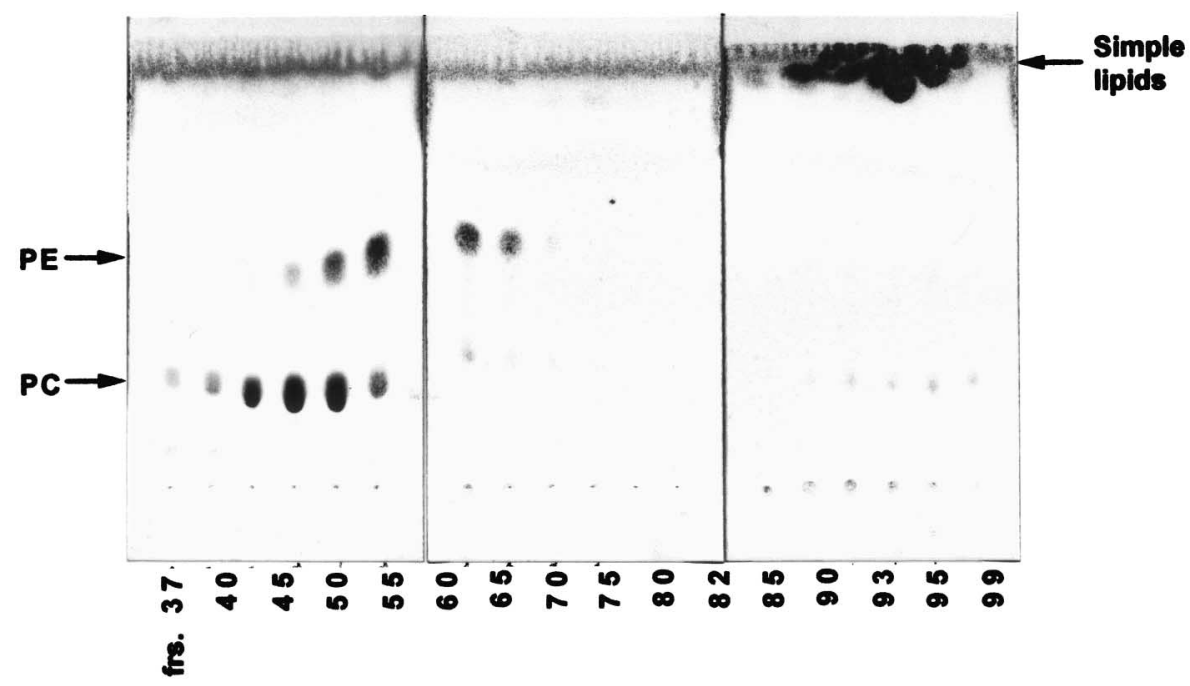

Fig. 4 Identification of phospholipids in the CCC fractions by silica gel thin layer chromatography Developing solvent: chloroform/methanol/water $(65: 25: 4)$ 
CCCにより，鷄卵卵黄中から PCと PE の分取を試みた. まず二相系の上層を固定相として，ポンプでカラム内に満 たした。次に卵黄の試料 $(0.75 \mathrm{~g})$ に二相系の上層と下層 をそれぞれ $2 \mathrm{ml}$ を加え溶かした。この試料液をループイ ンジェクターから注入し, カラムを $1000 \mathrm{rpm}$ で回転させ, 下層を移動相として溶離 $(1 \mathrm{ml} / \mathrm{min})$ した（Fig. 3)。し ばらくは上層である固定相がカラムから漏れて出てくる が, カラム内が平衡化されると移動相だけが溶出してくる $(\mathrm{SF})$ 。分配係数の小さな $\mathrm{PC}\left(K_{\mathrm{PC}}=0.87\right)$ が 40 画分から 60 画分に溶出し，分配係数の大きな $\mathrm{PE}\left(K_{\mathrm{PE}}=1.98\right)$ は 60 画分から 70 画分に溶出した。卵黄に大量混在する単純 脂質はカラム内の上層の固定相に保持されてカラムから溶 出しない. 移動相の送液を 80 画分で止め, 移動相に上層 を用いると, 単純脂質は 82 画分から 100 画分に溶出し, $\mathrm{PC}, \mathrm{PE}$ などのリン脂質から完全に分離できた。

各画分中のリン脂質と単純脂質はシリカゲル薄層クロマ トグラフィー（展開溶媒：クロロホルム：メタノール : 水 $=65: 25: 4)$ で確認した（Fig. 4). その結果, PCは 37 画分から 40 画分, PE は 60 画分から 70 画分を回収す れば純粋なリン脂質として得られると考えられた。また, 通常の CCC では分離する物質の分配係数に差があれば完 全に分離, 分取できるが，リン脂質のようにミセルを形成 する試料に対してはミセルを形成させない溶媒系を用いて CCC 分離する必要性が示された。

\section{文献}

1) Y. Ito, R. L. Bowman: Science, 167, 281 (1970).

2) Y. Ito, R. L. Bowman: J. Chromatogr. Sci., 8, 315 (1970).

3) T. Tanimura, J. J. Pisano, Y. Ito, R. L. Bowman: Science, 169, 54 (1970).
4) Y. Ito, R. L. Bowman: Anal. Chem., 43, 69A (1977).

5) Y. Ito: J. Chromatogr., 207, 161 (1981).

6) Y. Ito, J. Sandlin, W. G. Bowers: J. Chromatogr., 244, 247 (1982).

7) J. K. Snyeler, K. Nakanishi, K. Hostettman, M. Hostettman: J. Liq. Chromatogr., 7, 243 (1984).

8) W. Murayama, T. Kobayashi, Y. Kosuge, H. Yano, Y. Nunogaki, K. Nunogaki: J. Chromatogr., 239, 643 (1982).

9) Y. Ito: "High-Speed Countercurrent Chromatography", Edited by Y. Ito, W. D. Conway, (1996), (WileyInterscience, New York).

10) Y. Shibusawa, A. Yanagida, H. Shindo, Y. Ito: J. Liq. Chrom. \& Rel. Technol., 26, 1609 (2003).

11) 渡邊乾二：家禽卵のコレステロール (1), 畜産の研 究, 41, 703 (1987).

12) 長谷川峯夫：卵黄リン脂質，中村 良編：“卵の科 学”, p. 64 (1998), (朝倉書店).

13) K. Imaizumi : Agric. Biol. Chem., 53, 2469 (1989).

14) Y. Matsuda: Life Sci., 62, 813 (1998).

15) I. Kitagawa, Y. Hamamoto, M. Kobayashi: Chem. Pharm. Bull., 27, 1934 (1979).

16) H. Otsuka, T. Yamakawa: J. Biochem., 90, 247 (1981).

17) H. Otsuka, A. Suzuki, T. Yamakawa: J. Biochem., 94 2035 (1983)

18) J. G. Alvarez, J. Cazes, J. C. Touchstone, R. L. Grob: J. Liq. Chromatogr., 13, 3603 (1990).

19) G. Baudimant, M. Maurice, A. Landrein, G. Durand, P. Durand: J. Liq. Chrom. \& Rel. Technol., 19, 1793 (1996).

20) K. Matsuda, S. Matsuda, M. Sato, Y. Ito: J. Liq. Chrom. \& Rel. Technol., 25, 1255 (2002).

21) S. Matsuda, K. Matsuda, Y. Ito: J. Liq. Chrom. \& Rel. Technol., 26, 1135 (2003).

22) K. Hostettman: Planta Medica, 39, 1 (1980).

$23)$ E. G. Bligh, W. J. Dyer: Can. J. Biochem. Physiol., 37, 911 (1959).

24) H. K. Mangold: Am. J. Oil Chem. Soc., 41, 762 (1964).

25) W. D. Conway: "Countercurrent Chromatography: Apparatus, Theory and Applications", (1990), (VCH, New York).

\section{要旨}

高速向流クロマトグラフィー（HSCCC）により，鶏卵卵黄中のホスファチジルコリン（PC），ホスファ チジルエタノールアミン（PE）の大量分離を行った. 各種有機溶媒と水系とから構成される 34 種類の二相, 三相系について，各相の比を求めるとともに，二相系では上層と下層間，三相系では上層と中間層間におけ る PC，PEのミセルの形成状態や分配係数を求めた。その結果，酢酸メチル， $n$-ヘキサン，アセトニトリル， 水から構成される二相又は三相系では，PE はミセルを形成した。 クロロホルム: $n$-ヘプタン : $n$-ブタノー ル:メタノール : $60 \%$ 酢酸 $=2: 3: 2: 3: 5$ の二相系の上層を固定相, 下層を移動相に用いて（流量：1 $\mathrm{ml} / \mathrm{min})$, 鶏卵卵黄の高速向流クロマトグラフィー（HSCCC）分離を試みた。PC, PEのリン脂質は，単 純脂質から完全に相互分離が可能であった。 HSCCC 画分中の PC，PE，単純脂質は薄層クロマトグラフィ ーにより確認した。 